\section{Kamayas \\ Derual Tenee Agama}

http://jayapanguspress.penerbit.org/index.php/kamaya
Jayapangus Press

ISSN 2615-0913 (E)

Vol. 3 No. 2 (2020)

\title{
Implementasi Tri Hita Karana Sebagai Budaya Organisasi di The Royal Pita Maha Hotel
}

\author{
Oleh: \\ Ni Putu Yunita Anggreswari ${ }^{1}$, A.A.N. Oka Suryadinatha Gorda ${ }^{2}$ \\ ${ }^{12}$ Universitas Pendidikan Nasional Denpasar \\ 'tata.anggreswari@undiknas.ac.id, ${ }^{2}$ okagorda@gmail.com
}

\begin{tabular}{l} 
Keywords: \\
\hline Tri Hita Karana; \\
organizational \\
culture \\
\hline
\end{tabular}

Kata Kunci:

Tri Hita Karana; budaya organisasi

\begin{abstract}
Tri Hita Karana is a Hindu concept that has the understanding of the three causes of human welfare consisting of three elements which include Parhyangan, namely the Godhead, the Pawongan element of Humanity and the Palemahan the environmental elements. Tri Hita Karana is treated as an organizational culture in The Royal Pita Maha Hotel which is then applied by all members of the organization as a standard of behavior. The formulation of the problem in this study is "How is the implementation of Tri Hita Karana as organizational culture at The Royal Pita Maha Hotel?". The research methodology in this research is to use a qualitative approach with the type of research is descriptive type. Data collection techniques in this study used three techniques consisting of observation, interviews and documentation. The result of this research is the implementation of the Tri Hita Karana concept has been applied in accordance with the three elements in it which meet the elements of organizational culture criteria and organizational culture function elements.
\end{abstract}

\begin{tabular}{l} 
Abstrak \\
\hline Tri Hita Karana merupakan sebuah konsep Hindu yang \\
memiliki pengertian tiga penyebab kesejahteraan manusia terdiri \\
dari tiga unsur yang meliputi Parhyangan yaitu unsur \\
Ketuhanan, Pawongan unsur Kemanusiaan dan Palemahan \\
unsur lingkungan. Tri Hita Karana diberlakukan sebagai budaya \\
organisasi dalam The Royal Pita Maha Hotel yang kemudian \\
diterapkan oleh seluruh anggota organsiasi sebagai standar \\
perilaku. Adapun rumusan permasalahan dalam penelitian ini \\
adalah "Bagaimanakah implementasi Tri Hita Karana sebagai \\
budaya organisasi di The Royal Pita Maha Hotel?". Metodologi \\
penelitian dalam penelitian ini adalah menggunakan pendekatan \\
kualitatif dengan tipe penelitian adalah tipe deksriptif. Teknik \\
pengumpulan data dalam penelitian ini menggunakan tiga teknik \\
yang terdiri dari obervasi, wawancara dan dokumentasi. Adapun \\
hasil dari penelitian ini adalah implementasi dari konsep Tri Hita
\end{tabular}


Karana sudah diterapkan sesuai dengan tiga unsur yang ada di dalamnya yang mana memenuhi unsur dari kriteria budaya organisasi dan unsur fungsi budaya organisasi.

\section{Pendahuluan}

Tri Hita Karana merupakan konsep yang diadopsi dari ajaran agama Hindu. Munculnya istilah Tri Hita Karana pertama kali adalah ketika diselenggarakannya Konferensi Daerah 1 Badan Perjuangan Umat Hindu Bali bertempat di Perguruan Dwijendra Denpasar pada tanggal 11 November 1966. Adapun pengertian dari Tri Hita Karana sendiri adalah tiga penyebab terjadinya kebahagiaan yang mana Tri artinya tiga, Hita artinya kebaagiaan dan karana artinya penyebab. Adapun yang dimaksudkan dengan tiga penyebab tersebut adalah adanya keharmonisan antara manusia dengan Tuhan (Parhyangan), adanya keharmonisan antara manusia dengan sesamanya (Pawongan) dan adanya keharmonisan hubungan antar manusia dengan alam (Palemahan). Makna hakiki kalau Tri Hita Karana dinyatakan dalam ungkapan lebih umum adalah bahwa Tri Hita Karana bermakna sebagai konsep harmoni dan kebersamaan (Windia \& Ratna, 2011).

Konsep Tri Hita Karana merupakan konsep yang sudah diadopsi sebagai pedoman hidup dan diimplementasikan dalam setiap keseharian masyarakat, tidak jarang beberapa organisasi turut mengadopsi Tri Hita Karana sebagai sebuah budaya organisasi. Diadopsinya konsep Tri Hita Karana sebagai budaya organisasi tentu membutuhkan konsistensi dalam implementasinya disetiap kegiatan organisasi. Bahkan kini implementasi dari konsep Tri Hita Karana sudah dilakukan secara professional dengan melibatkan Yayasan Tri Hita Karana sebagai lembaga akreditasi. Dalam penilaian Tri Hita Karana di sebuah organisasi dilakukan dengan observasi dan wawancara yang menganalisis mengenai seberapa jauh konsep Tri Hita Karana diterapkan dalam organisasi tersebut.

Salah satu organisasi yang turut mengimplementasikan konsep Tri Hita Karana adalah The Royal Pita Maha Hotel. The Royal Pita Maha Hotel merupakan sebuah hotel yang berlokasi di Ubud, Gianyar. Hotel ini sudah berturut-turut mendapatkan reward dari Yayasan Tri Hita Karana karena The Royal Pita Maha Hotel menerapkan konsep Tri Hita Karana sebagai sebuah budaya organisasi yang diterapkan sebagai pedoman dan nilainilai yang dianut oleh sebuah organisasi. Budaya organisasi bersumber dari kebudayaan sebagai seperangkat nilai, kepercayaan, cara berpikir, serta pemahaman anggota organisasi agar mereka berpikir dan bertindak secara benar dalam organisasi. Budaya 
organisasi dapat dipahami dalam dua level, yakni level visible/nyata (budaya yang terlihat, terdengar, teraba dan terasa) dan level invisible/tidak nyata (budaya dalam nilai dan norma yang tidak ditangkap indra). Menurut Kilman (dalam Liliweri, 2014) dikatakan bahwa, "budaya organisasi adalah cara kita melakukan sesuatu di sekeliling kita dengan suatu implikasi bahwa cara kita melakukan sesuatu itu berbeda dengan cara orang lain melakukan hal yang sama".

Budaya organisasi memiliki peranan yang penting dalam sebuah organisasi yang mana meliputi pembentukan sebuah identitas yang membedakan organisasi satu dengan organisasi lainnya. Adapun yang kemudian membuat peneliti untuk melakukan penelitian ini adalah bahwa tidak semua organisasi menerapkan konsep Tri Hita Karana dalam organisasinya dan menjadikan konsep Tri Hita Karana sebagai tatanan perilaku yang diterapkan dalam kehidupan organisasi. Hal tersebut membuat peneliti berfokus pada penelitian dengan judul "Implementasi Tri Hita Karana sebagai Budaya Organisasi di The Royal Pita Maha Hotel”. Adapun rumusan masalah pada penelitian ini adalah : (1) Bagaimanakah implementasi Tri Hita Karana sebagai Budaya Organisasi di The Royal Pita Maha Hotel.

\section{Metode}

Pendekatan yang digunakan dalam penelitian ini adalah pendekatan kualitatif. Pendekatan kualitatif menurut Taylor dan Bogdan diartikan sebagai "penelitian yang menghasilkan data deskriptif mengenai kata-kata lisan maupun tertulis dan tingkah laku yang diamati dari orang-orang yang diteliti” (Suyanto, 2015). Adapun tipe dari penelitian ini adalah tipe deskriptif. Tipe deskriptif dimana data yang dikumpulkan berbentuk kata, kalimat, pernyataan dan konsep. Deskriptif merupakan data-data yang dikumpulkan adalah berupa kata-kata dan gambar sehingga laporan penelitian akan berisi kutipankutipan data untuk memberikan gambaran penyajian laporan. Teknik pengumpulan data merupakan cara peneliti mengumpulkan data dimana data dapat diperoleh melalui teknik wawancara, dokumentasi dan obersvasi. Adapun teknik pengumpulan data yang dilakukan dalam penelitian ini adalah: (1) Observasi, observasi merupakan teknik pengumpulan data dengan cara melakukan pengamatan langsung terhadap objek penelitian. Teknik pengumpulan data dengan cara ini akan menghasilkan catatan yang sistematis sesuai dengan tujuan penelitian dan dapat dikontrol keandalannya; (2) Wawancara, wawancara adalah tanya jawab lisan antara dua orang atau lebih secara 
langsung. Dalam penelitian ini dilakukan wawancara mendalam. Wawancara mendalam menurut Iskandar (2019) adalah "suatu proses untuk kepentingan penelitian dengan cara dialog antara peneliti dengan informan atau subyek yang berhubungan dengan penelitian dalam konteks observasi partisipasi”(Iskandar, 2019); (3) Dokumentasi merupakan suatu metode pengumpulan data yang mana informasi yang diperoleh berupa catatan atau data yang diperoleh dari pihak lain. Hamidi (2010) mengatakan bahwa "Dokumentasi adalah cara pengumpulan data yang diperoleh dari catatan (data) yang telah tersedia atau telah dibuat oleh pihak lain" (Hamidi, 2010). Bungin (2008) juga menyatakan bahwa "kumpulan data yang meliputi dokumen dapat berupa monument, artefak, foto, tape, disc, CD, harddisk, flashdisk dan sebagainya"(Burhan, 2008).

Terdapat tiga tahapan dalam menganalisis data kualitatif yang meliputi Reduksi data (data reduction), penyajian data (data display) dan penarikan kersimpulan dan verifikasi data (verifying). (1) Reduksi data (data reductions) meliputi merangkum data, memilih hal pokok, memfokuskan data pada hal-hal penting yang sesuai dengan tema dan pola penelitian. Data yang telah direduksi akan memberikan gambaran yang lebih jelas karena sudah difokuskan kepada data-data yang terkait penelitian. Proses reduksi data bertujuan untuk melakukan pengumpulan data (Sugiyono, 2015); (2) Penyajian data (data display) meliputi pengumpulan informasi yang sudah tersusun yang memungkinkan adanya penarikan kesimpulan dan pengambilan tindakan. Bentuk penyajian data dapat berupa matriks, grafik, jaringan bagan, narasi dan sebagainya (Prastowo, 2012); (3) Penarikan kesimpulan atau verifikasi merupakan simpulan yang disajikan dalam bentuk deskriptif dengan berpedoman pada kajian penelitian (Gunawan, 2013). Dalam pengujian keabsahan data dilakukan dengan menggunakan teknik triangulasi sumber, dimana menggali data yang sama dari sumber berbeda sehingga akan dilaksanakan wawancara dengan beberapa narasumber untuk menguji keabsahan data.

\section{Hasil dan Pembahasan}

\section{Implementasi Konsep Tri Hita Karana di The Royal Pita Maha Hotel}

Konsep Tri Hita Karana merupakan konsep yang diadopsi dari ajaran agama Hindu. Istilah Tri Hita Karana pertama kali muncul pada tanggal 11 Nopember 1966, pada waktu diselenggarakan Konferensi Daerah 1 Badan Perjuangan Umat Hindu Bali bertempat di Perguruan Dwijendra Denpasar. Konferensi tersebut diadakan berlandaskan kesadaran umat Hindu akan dharmanya untuk berperan serta dalam pembangunan bangsa 
menuju masyarakat sejahtera, adil dan makmur berdasarkan Pancasila. Kemudian istilah Tri Hita Karana ini berkembang, meluas, dan memasyarakat.

Tri artinya tiga, Hita artinya kebahagiaan, dan Karana artinya penyebab. Jadi Tri Hita Karana berarti tiga penyebab terjadinya kebahagiaan. Adapun yang dimaksudkan dengan tiga penyebab tersebut adalah adanya keharmonisan hubungan antara manusia dengan Tuhan (Parhyangan), adanya keharmonisan hubungan antara manusia dengan sesamanya (Pawongan) dan adanya keharmonisan hubungan antar manusia dengan alam (Palemahan). Makna hakiki kalau Tri Hita Karana dinyatakan dalam ungkapan lebih umum adalah bahwa Tri Hita Karana dapat bermakna sebagai konsep harmoni dan kebersamaan (Windia \& Ratna, 2011).

Pada dasarnya aspek Parhyangan, Palemahan dan Pawongan adalah bagian dari sebuah sistem dan karenanya ketiga aspek tersebut saling berkaitan. Sebagai sebuah sistem, maka sistem itu harus mempunyai tujuan. dalam hal ini tujuannya tiada lain adalah hakikat dari Tri Hita Karana itu sendiri, yakni tercapainya harmoni dan kebersamaan. Pemilik dari The Royal Pita Maha Hotel mengatakan bahwa "Pada dasarnya aspek Parhyangan, Palemahan dan Pawongan adalah bagian dari sebuah sistem dan karenanya ketiga aspek tersebut saling berkaitan. Sebagai sebuah sistem, maka sistem itu harus mempunyai tujuan. dalam hal ini tujuannya tiada lain adalah hakikat dari Tri Hita Karana itu sendiri, yakni tercapainya harmoni dan kebersamaan bukan semata-mata mendirikan bisnis hanya untuk keuntungan semata, namun disini menerapkan Tri Hita Karana itu sendiri dalam mempertahankan keberadaan bisnis ini dan diterima dengan baik oleh masyarakat sekitar".

Adapun implementasi konsep Tri Hita Karana di The Royal Pita Maha Hotel adalah sebagai berikut:

a. Parhyangan

Parhyangan adalah sebuah konsep yang menginginkan adanya harmoni antara manusia dengan Tuhan. Dalam kaitannya dengan kegiatan bisnis, haruslah juga disadari bahwa aktivitas manusia yang berbisnis itu adalah suatu persembahan kepada Tuhan.

1) Dari segi fisik hotel ini memiliki tempat suci yang terdiri dari Padmasana dan penunggun karang sesuai dengan konsep arsitektur adat Bali.

2) Pihak hotel turut memberikan kontribusi dalam kegiatan keagamaan di Pura sekitar, seperti contohnya dengan dana punia. 
3) Pihak hotel turut terlibat dalam upaya pelestarian dan pengembangan tradisi keagamaan di hotel, dalam hal ini hotel memberikan fasilitas pelatihan/pembinaan untuk pelestaian tradisi keagamaan kepada karyawan.

4) Pihak hotel memiliki pola kerja untuk dapat memberikan kesempatan penuh kepada karyawan melaksanakan kegiatan agama (piodalan) mulai dari proses pembuatan sarana hingga akhir ritual.

5) Seluruh karyawan hotel turut bertanggung jawab dalam pemeliharaan tempat suci yang ada didalam hotel.

\section{b. Pawongan}

Pawongan adalah sebuah konsep yang menginginkan adanya harmoni antara manusia dengan sesamanya. Adapun penerapan konsep ini di The Royal Pita Maha Hotel adalah sebagai berikut:

1) Pihak hotel memiliki program pengembangan organisasi sosial di sekitar hotel, dalam hal ini pihak hotel turut memberikan bantuan dalam bentuk uang ataupun jasa kepada organisasi disekitar hotel seperti sekehe banjar ataupun STT (Sekehe Teruna Teruni)

2) Pihak hotel turut berkontribusi dalam berbagai kegiatan dalam upaya pelestarian budaya Bali seperti misalnya memberikan bantuan berupa barang ataupun jasa dalam setiap kegiatan keagamaan yang menunjang pelestaria budaya Bali.

3) Pihak hotel turut memberikan kepedulian terhadap masalah sosial yang terjadi disekitar hotel, misalnya membantu pelaksanaan upacara dan pelaksanaan berbagai ritual keagamaan yang dilaksanakan oleh masyarakat disekitar hotel.

4) Pihak hotel menjaga keserasian hubungan antara karyawan dengan pihak manajemen, dalam hal ini praktisi Public Relations memegang peranan penting untuk turut mewujudkan hubungan yang harmonis dan menciptakan iklim kerja yang nyaman untuk semua pihak dalam hotel itu sendiri.

5) Pihak hotel memberikan perlakuan yang sama kepada seluruh karyawan dan tidak membeda-bedakan karyawan, serta memberikan hak yang porposional kepada seluruh karyawan, pihak hotel juga memberikan penghargaan kepada karyawan yang berprestasi. 
6) Pihak hotel melaksanakan kerjasama dengan stakeholder lain yakni seniman lokal untuk mengajak para wisatawan asing menyaksikan kesenian dan aktivitas budaya Bali seperti tari Bali, tari Kecak dan tari Barong.

7) Pihak hotel memberikan asuransi kesehatan kepada seluruh karyawan, hal ini merupakan salah satu upaya dalam mewujudkan keharmonisan hubungan masyarakat internal dalam organisasi.

\section{c. Palemahan}

Palemahan adalah sebuah konsep yang menginginkan adanya harmoni antara manusia dengan lingkungan alam sekitarnya. Pelaku bisnis juga harus menjaga harmoni dengan lingkungan alam sekitarnya. Adapun penerapan konsep ini di The Royal Pita Maha Hotel adalah sebagai berikut:

1) Pihak hotel mampu menangani sampah dengan baik dan meminimalisasi produksi sampah yang dibuang ke lingkungan, dalam hal ini pihak hotel memisahkan sampak organic dan anorganik yang mana sampah organis akan diolah menjadi pupuk.

2) Pihak hotel mampu menangani limbah dengan baik dan meminimalisasi produksi limbah yang dibuang ke lingkungan, dalam hal ini pihak hotel memiliki pengolahan limbah yang mana limbah akan disaring dan disaring hingga menjadi air dan kemudian dipergunakan kembali untuk pengairan tanaman dilingkungan hotel sehingga mencegah pembuangan limbah ke lingkungan.

3) Hotel memanfaatkan lahan dengan proporsi yang sesuai dengan konsep Tri Hita Karana, dalam hal ini luas tanah yang digunakan untuk bangunan adalah $60 \%$ dan $40 \%$ untuk tumbuh-tumbuhan.

4) Pihak hotel memanfaatkan lahan secara efisien dan tidak mengubah tata letak lahan yang memang sudah ada.

5) Lingkungan hotel memiliki keanekaragaman flora dan melestarikan beberapa tanaman yang langka dan dilindungi serta membudidayakan tanamantanaman yang memiliki manfaat untuk kesehatan.

\section{Konsep Tri Hita Karana sebagai Budaya Organisasi}

Berdasarkan hasil penelitian yang ditemukan di lapangan, maka implementasi konsep Tri Hita Karana di The Royal Pita Maha Hotel sudah memenuhi unsur-unsur 
karakteristik budaya organisasi yang dikemukakan oleh Luthans (dalam Jondar, 2015). Implementasi Tri Hita Karana di The Royal Pita Maha Hotel sudah memenuhi unsur norma, dimana adanya standar perilaku yang diberlakukan dalam sebuah organisasi yang harus ditaati oleh seluruh anggota organisasi. Dalam The Royal Pita Maha Hotel adanya standar perilaku yang harus diikuti mengacu pada implementasi Tri Hita Karana dalam elemen Parhyangan yang mana pihak hotel berkomitemen untuk turut berkontribusi dalam kegiatan kegamaan di Pura sekitar dengan dilaksanakannya dana punia sehingga manajemen hotel harus mengikuti norma tersebut. Pihak hotel turut terlibat dalam upaya pelestarian dan pengembangan tradisi keagamaan di hotel, dalam hal ini hotel memberikan fasilitas pelatihan/pembinaan untuk pelestaian tradisi keagamaan kepada karyawan sehingga baik dari manajemen dan karyawan turut andil dalam norma pelestarian tradisi yang sudah ditetapkan oleh pihak hotel. Berdasarkan penjabaran tersebut, maka Tri Hita Karana sudah memenuhi unsur norma dalam karakteristik budaya organisasi.

Selain unsur norma, karakeristik budaya organisasi lainnya seperti Filosofi juga sudah dipenuhi. Filosofi merupakan kebijakan bagaimana karyawan diperlakukan (Jondar \& Sudarsono, 2015). Dalam implementasi Tri Hita Karana di The Royal Pita Maha Hotel dalam unsur Pawongan atau unsur kemanusiaan sudah mengatur mengenai bagaimana karyawan diperlakukan. Dalam hal ini pihak hotel memiliki komitmen untuk menjaga keserasian hubungan antara karyawan dengan pihak manajemen, pihak hotel memberikan perlakukan yang sama kepada seluruh karyawan serta adanya reward yang diberikan kepada karyawan berprestasi. Dengan demikian kebijakan-kebijakan mengenai bagaimana karyawan diperlakukan sudah memenuhi unsur filosofi dari karakteristik budaya organisasi.

Karakteristik budaya organisasi lainnya yang juga dipenuhi dalam implementasi Tri Hita Karana di The Royal Pita Maha Hotel juga menyangkut iklim organisasi. Iklim organisasi merupakan cara para anggota organisasi berinteraksi dengan pelanggan internal dan eksternal (Jondar \& Sudarsono, 2015). Dalam memenuhi unsur iklim organisasi, implementasi Tri Hita Karana meliputi adanya komitmen dari pihak hotel untuk mengembangkan organisasi sosial di sekitar hotel seperti sekehe banjar atau STT (Sekehe Teruna Teruni), pihak hotel turut berkontribusi dalam berbagai kegiatan dalam upaya pelestarian budaya Bali seperti misalnya memberikan bantuan berupa barang ataupun jasa dalam setiap kegiatan keagamaan yang menunjang pelestarian budaya Bali, 
serta adanya komitmen dalam memberikan kepedulian terhadap masalah sosial yang terjadi disekitar hotel. Implementasi tersebut merupakan tata cara yang sudah ditetapkan oleh organisasi dalam interaksi dengan stakeholder yang terlibat.

Implementasi Tri Hita Karana di The Royal Pita Maha Hotel memenuhi beberapa fungsi dari budaya organisasi menurut Luthans (dalam Jondar \& Sudarsono, 2015) dimana fungsi budaya organisasi yang telah dipenuhi meliputi (1) budaya memiliki peran dan batasan tertentu yang menjadi pembeda antara satu organisasi dengan organisasi lainnya. Dimana adanya peran berupa komitmen-komitmen yang sudah diberlakukan oleh pihak hotel untuk dijadikan batasan dan keunikan atau pembeda dengan organisasi lainnya. (2) Budaya memiliki fungsi menyampaikan identitas kepada anggota organisasi, fungsi kedua dipenuhi dengan banyaknya aktivitas Pawongan atau unsur kemanusiaan yang diimplementasikan di The Royal Pita Maha Hotel dalam menyampaikan identitas kepada anggota internal organisasi itu sendiri. (3) Budaya dapat mendorong stabilitas sistem sosial dimana budaya merupakan suatu ikatan sosial yang mengikat rasa kebersamaan dalam organisasi dengan menyediakan standar-standar yang sesuai mengenai perilaku anggota organisasi. Adapun implementasi dari fungsi ketiga dalam kaitannya dengan konsep Tri Hita Karana yakni adanya komitmennya menjaga hubungan yang baik antara karyawan dan manajemen, adanya penghargaan kepada karyawan berpestasi, adanya program pengembangan aktivitas seni bagi komunitas eksternal yang ada disekitar organisasi serta adanya kerjasama yang efektif antar anggota organisasi dalam kerjasamanya mengimplementasikan konsep Tri Hita Karana secara bersamasama secara berkesinambungan. (4) Budaya organisasi berfungsi sebagai pembentuk perilaku serta sikap anggota organisasi, dimana adanya standar yang sudah ditetapkan sebagai acuan bagi perilaku seluruh karyawan untuk turut bekerjasama dalam mengimplementasikan konsep Tri Hita Karana itu sendiri.

\section{Kesimpulan}

Implementasi konsep Tri Hita Karana di The Royal Pita Maha Hotel sebagai budaya organisasi sudah diimplementasikan dengan tiga unsur Tri Hita Karana yang meliputi unsur Ketuhanan (Parhyangan), unsur Kemanusiaan (Pawongan), unsur Lingkungan (Palemahan). Implementasi Tri Hita Karana sudah memenuhi unsur dari budaya karakteristik dari budaya organsisasi serta sudah terpenuhinya unsur fungsifungsi dari budaya organisasi. Dengan demikian dapat disimpulkan bahwa konsep Tri 
Hita Karana di The Royal Pita Maha Hotel sudah sesuai dengan definisi dari budaya organsiasi itu sendiri dimana Tri Hita Karana dipahami sebagai nilai, keyakinan, pemahaman dan normal perilaku yang dipahami dan diterapkan secara bersama oleh seluruh anggota organisasi.

\section{Daftar Pustaka}

Burhan, B. (2008). Penelitian Kualitatif: Komunikasi, Ekonomi, Kebijakan Publik, dan Ilmu Sosial lainnya. Jakarta: Kencana Prenada Media Group.

Gunawan, I. (2013). Metode Penelitian Kualitatif: Teori dan Praktik. Jakarta: PT Bumi Aksara.

Hamidi. (2010). Metode Penelitian dan Teori Komunikasi. Malang: UMM Press.

Iskandar. (2019). Metodelogi Penelitian Kualitatif. Jakarta: Gaung Persada.

Jondar, Aloysius \& Sudarsono, H. (2015). Karakteristik Budaya Organisasi di Klinik Dr Eko, Surabaya. Jurnal Sosial Humaniora Universitas Teknologi Surabaya.

Liliweri, A. (2014). Sosiologi dan Komunikasi Organisasi. Jakarta: Bumi Aksara.

Prastowo, A. (2012). Metode Penelitian Kualitatif Dalam Perspektif Rancangan Penelitian. Jakarta: Arruzzmedia.

Sugiyono. (2015). Metode Penelitian Kombinasi. Bandung: Alfabeta.

Suyanto, Bagong, dkk. (2015). Metode Penelitian Sosial. Surabaya: Airlangga University Press.

Windia, Wayan \& Ratna, K. D. (2011). Analisis Bisnis Berlandaskan Tri Hita Karana. Denpasar: Udayana University Press. 